\title{
DETEKSI MOBIL AMBULANCE MENGGUNAKAN OPERATOR SOBEL
}

\author{
Prima Giri Pamungkas ${ }^{1}$, Kusrini ${ }^{2}$, Hanif Al Fatta ${ }^{3}$ \\ Magister Teknik Informatika, Universitas AMIKOM Yogyakarta \\ Email : prima.pamungkas@ @students.amikom.ac.id ${ }^{1}$, Kusrini@ Amikom.ac.id ${ }^{2}$, \\ Hanif.a@amikom.ac.id ${ }^{3}$
}

\begin{abstract}
ABSTRAK
Pengolahan data citra digital dalam pendeteksi kendaraan darurat yang dilakukan oleh sistem komputer mampu mendapatkan data serta hasil informasi yang lebih baik dan efisien. Salah satu metode yang digunakan dalam proses penelitian gambar digital adalah deteksi tepi. Dalam fungsinya motode ini merupakan cara mengidentifikasi garis tepi objek gambar sehingga informasi garis pada objek dapat di ketahui titik tepi yang diterapkan untuk mengidendifikasi tepi text ambulance yang terdapat pada kendaraan ambulance.penelitian ini, peneliti melakukan indentifikasi terhadap kendaraan ambulance yang difokuskan kepada text ambulance yang terpasang pada kendaraan ambulance dalam pengolahan gambar dan ekstraksi fitur text ambulance. Data yang capture dengan format jpg dan 450x660 pixel yang terdiri dari 150 gambar oleh kamera dengan menggunakan citra gray scale dan sobel didapatkan hasil 4 gambar digital yang dipilih secara acak.
\end{abstract}

Kata Kunci: Grayscale, Kendaraan Ambulance, Operator Sobel

\section{ABSTRACT}

Digital image data processing in emergency vehicle detection performed by a computer system is able to get data and information results that are better and more efficient. One method used in the digital image research process is edge detection. In its function, this method is a way to identify the outline of the image object so that the outline information on the object can be identified the edge point that is applied to identify the edge of the ambulance text contained in the ambulance vehicle. on ambulance vehicles in image processing and feature extraction of the ambulance text. Data captured in the jpg format and $450 x 660$ pixels consisting of 150 images by the camera using gray scale and sobel images obtained 4 randomly selected digital images.

Keywords: Grayscale, Vehicles Ambulance, Operator Sobel

\section{PENDAHULUAN}

Citra sebagai bagian dari suatu proses pengolahan citra untuk membagi citra menjadi beberapa bagian, dengan tujuan untuk mengisolasi atau menemukan objek di dalam citra tersebut. Dalam Proses tersebut akan berhenti jika objek telah mendapatkan hasil dalam meningkatkan proses keberhasilan itu diperlukan pemilihan metode yang baik dan dalam hal ini proses dilakukan menggunakan deteksi tepi mengunakana metode sobel.Objek yang akan di uji merupakan Kendaraan ambulance yaitu sebuah unit transportasi 
kendaraan medis yang di kelola pihak rumah sakit dan didesign khusus yang berbeda dengan transportasi lainnya. Seperti halnya kendaraan ambulance yang digunakan untuk menangani pasien gawat darurat dalam memberikan pertolongan pertama kepada korban/pasien dan melakukan perawatan secara insentif selama dalam perjalan menuju rumah sakit. Dikarenakan itu perlunya pendeteksian terhadap kendaraan darurat dalam hal penelitian ini berupa kendaraan ambulance dalam menjalankan tugas social kemasyarakatan di bidang kesehatan medis untuk dapat mengetahui tingkat detail yang terdapat pada kendaraan ambulance tersebut bisa berupa text ambulance yang terdapat pada kendaraan ambulance tersebut yang terletak di bagian depan kendaraan.

\section{LANDASAN TEORI}

Dari Penelitian yang telah dilakukan deteksi tepi dengan objek wajah dan kendaraan dengan menggunakan deteksi tepi menggunakan LoG dan Canny menunjukkan bawah terdapat perbedaaan kelebihan dan kekurangan di setiap metode yang ada dengan menggunakan canny deteksi noise tidaklah tampak dan dalam mendeteksi wajah sangatlah jelas sedangkan deteksi LoG terhadap noise tampak serta dengan tingkat kejelasan wajah yang dideteksi dengan kedua metode tersebut perbandingan selisih waktu tidak terpaut jauh yaitu 0,01detik dari setiap metode yang di pakai(Pada and Ct., 1969) Dari deteksi tempat parkir yang kosong menggunakan objek kapasitas parkir tiga area, satu kendaraan dan 2 area di sekitar kosong atau dua kendaraan dengan satu area parkir kosong menunjukan deteksi tepi terhadap parkir yang kosong dan berisi berjalan dengan baik(Komputer., 2017). Dari pendeteksian tepi beberapa objek yang dilakukan dengan mengunakan metode Prewitt dan sobel menujukan hasil nilai yang lebih baik terhadap metode sobel dibandingkan dengan prewitt dikarenakan tingkat kontras yang tinggi dan tepi yang lebih jelas membuat sobel lebih unggul di banding prewitt yang dilakukan dengan menggunakan perhitungan secara manual(Indraani et al., 2014). Dari sistem klasifikasi jenis kendaraan dengan teknik citra digital menunjukan bahwa sistem mampu mendeteksi dan mengkalsifikasi jenis kendaraan dengan tingkat akurasi yang berbeda dengan jarak yang tertentu dan semakin dekat/focus objek yang di ambil mkan akan di dapat hasil yang semakin baik pula dengan menerapkan Artificial Intelligent dan Fuzzy logic dengan pengambilan Objek berupa Video pada CCTV(Pribadi and Naseer., 2014). Dalam penelitian selajutnya menjelaskan tentang deteksi analisis terhadap ikan koi dalam penelitian ini metode sobel di gunakan untuk tingkat kecerahan dan mengidentifikasi titik-titik pada citra serta bertujuan untuk membentuk sejumlah kurva yang saling terhubung yang ngengidentifikasi batasan objek dengan memadukan metode sobel dan klasifikasi K-Nearest Neighbor untuk dapat lebih mengetahui jenis ikan koi yang di maksud(Arief and Kom., 2017). Dalam mengidentifikasi beberapa objek/gambar penelitian sebelumnya mengangkat beberapa perbandingan antara metode kirsch, robinson, sobel dan prewitt hasil dari penelitian tersebut menunjukan tingkata pengamatan secara visual,jumlah paling tinggi pada pixel tertuju pada metode kirsch dikarenakan metode kirsch menggunakan 7 kernel dengan mengamati hasil uji secara visual dan batasan pada penerimaan pixel penyusun dengan dominan bentuk tei yang lurus baik secara vertical,horizontal, maupun diagonal(Lusiana., 2013)

\section{METODE PENELITIAN}

Pada Penelitian ini objek yang dipilih adalah Kendaraan ambulance dengan mendeteksi text"ambulance"yang terdapat pada mobil ambulance dengan operator 
sobel pengumpulan data yang dilakukan berupa gambar yang terdapat pada ambulancekaroseri dan Foto manual menggunakan Hp kamera vivo 7. Dengan object scalling untuk menyamakan ukuran objek yang akan di uji dan di kenali lebih lanjut apakah benar kendaraan ambulance atau bukan proses ini diperlukan sebelum tahap pengenalan objek yang akan menjadi masukan harus memiliki ukuran pixel yang sama seperti tahap penelitian.

\subsection{Operator Sobel}

Deteksi tepi sobel ini mempunyai bentuk matriks 3x3 dengan Gx dan Gy yaitu :

\begin{tabular}{|c|c|c|}
\hline-1 & -2 & -1 \\
\hline 0 & 0 & 0 \\
\hline 1 & 2 & 1 \\
\hline
\end{tabular}

$\mathrm{G}_{\mathrm{x}}$

\begin{tabular}{|l|l|l|}
\hline-1 & 0 & 1 \\
\hline-2 & 0 & 2 \\
\hline-1 & 0 & 1 \\
\hline
\end{tabular}

$G_{y}$
Gambar 1. Matriks Operator Sobel

\subsection{Grayscale}

Grayscale atau abu-abu pada sebuah citra digital adalah image yang pada setiap pixelnya hanya berisikan informasi intensitas warna putih dan hitam, image pada grayscale juga di sebut monokromatik karena tidak memiliki warna lain selain variasi intensitas putih dan hitam. Sebuah image yang di jadikan grayscale akan terkesan berbeda bila dibandingkan dengan image berwarna.

\subsection{Alur Penelitian}

Alur pada penelitian ini menunjukkan keterangan sebagai berikut :

a. Data yang diambil melalui internet berupa data karoseri ambulance yang di pilih secara random yang di tunjukkan pada gambar 6 dan data yang di ambil secara manual menggunakan foto melalui kamera Hp langsung diambil di beberapa rumah sakit yang ada seperti yang terdapat pada gambar 3 dan gambar 4 .

b. Citra dinormalisasi dengan membuat penyimpanan database untuk citra asli mobil ambulance.

c. Memasukan Citra asli untuk dilakukan proses perubahan uji objek ke sobel.

d. Mengcrop hasil dan zoom hasil uji dari perubahan objek ke sobel.

e. Mencocokkan titik-titik fitur pada citra uji dan citra asli.

f. Hasil dari crop dan sobel di simpan nilai ujinya ke database

g. Mendapatkan hasil kecocokan dalam teteksi tepi yang di lakukan terhadap objek mobil ambulance.

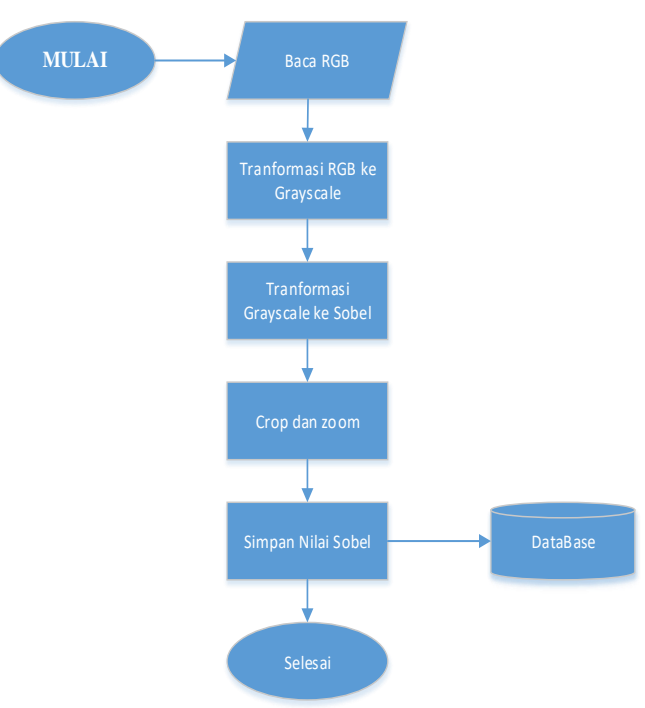

Gambar 2. Alur penelitian

\section{HASIL DAN PEMBAHASAN}

Dari data uji yang diambil telah membentuk citra digital yang memiliki ukuran 450x660 pixel. Pada penelitian ini penguji telah melakukan suatu pemilihan yang random untuk citra mana saja yang 
akan di analisis. Deteksi tepi menggunakan operator sobel dapat digunakan dalam mendeteksi tepi yang terdapat pada objek dan termasuk tulisan yang terpasang pada objek tersebut. Seperti pada objek yang telah diambil melalui kamera $\mathrm{Hp}$ yang di tunjukkan melalui gambar 3-4 yaitu :

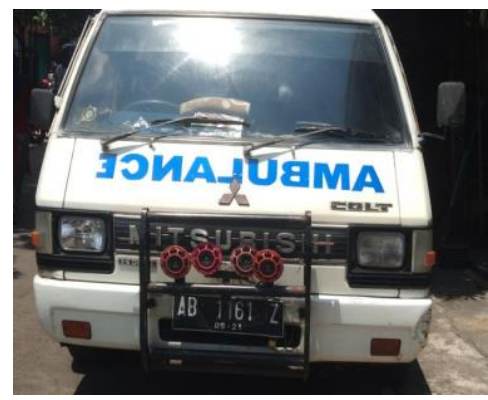

Gambar 3. Foto dari kamera

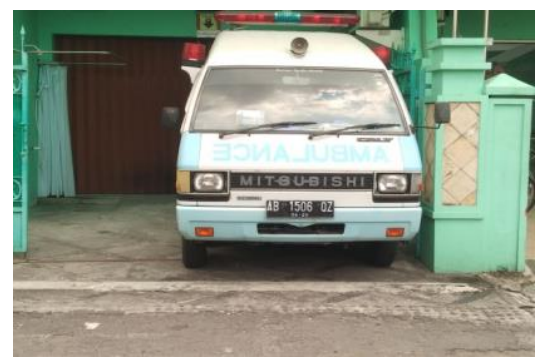

Gambar 4. Foto dari kamera

pengujian grayscale dan sobel yang dilakukan pada proses dibawah ini :

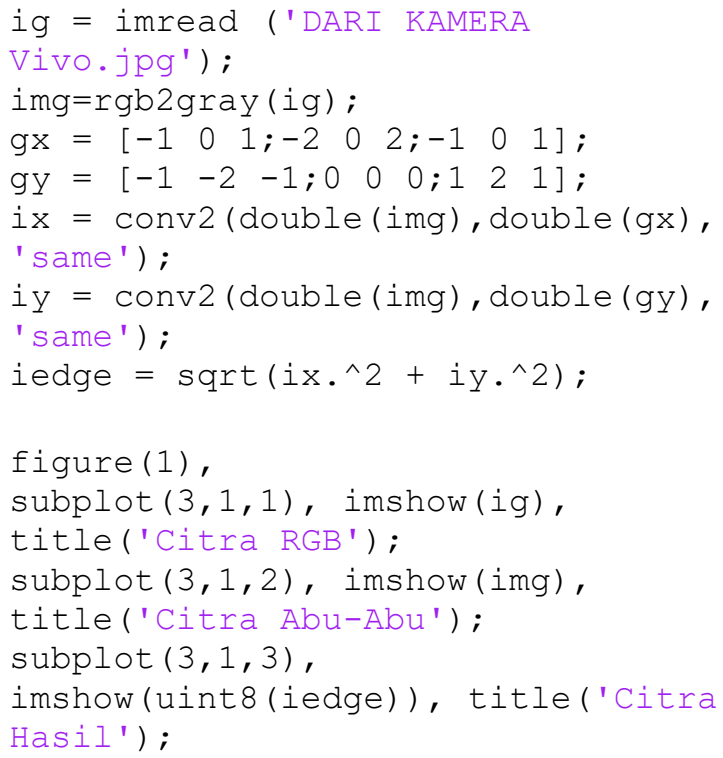

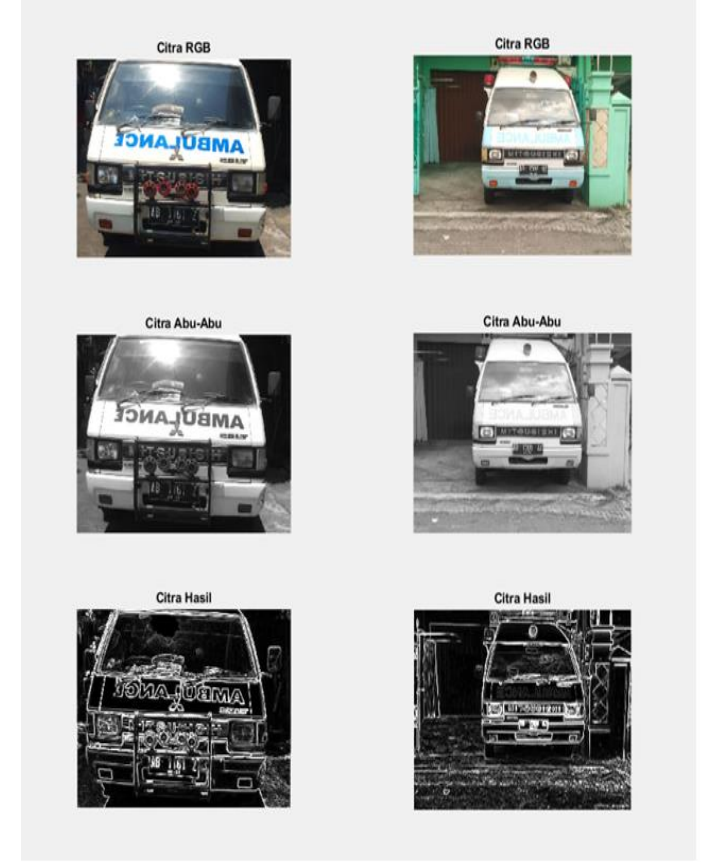

Gambar 5. Hasil uji Grayscale dan Sobel

Data yang di capture dari kamera hp vivo dengan pengambilan gambar yang dekat dan sesuai menunjukkan pada citra RGB yang di hasilkan gambar 3-4 mempunyai tingkat kejelasan yang baik yang kemudian dilanjutkan ke grayscale dalam proses ini pada gambar yang ke 4 didapatkan text gambar yang samar/blur dikarenakan warna pada text. Dalam proses selanjutnya yaitu hasil tepi sobel menunjukkan bawah pada gambar 3 terdapat kejelasan text dan dapat di baca sedangkan pada gambar 4 masih mendapatkan hasil yang samar/blur pada text gambar yang yang di peroleh

Data asli yang diambil melalui ambulance karoseri [dot] com dapat dilihat dari gambar 6 yaitu :
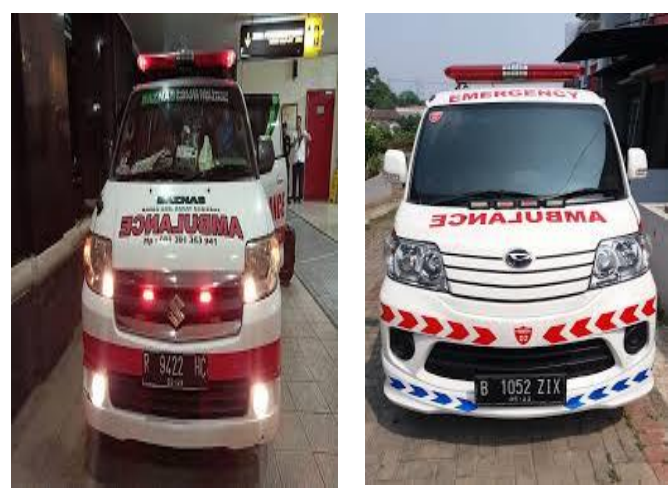

Gambar 6. Data ambulance karoseri 
Pengujian grayscale dan sobel yang dilakukan yang ditunjukkan pada proses dibawah ini :

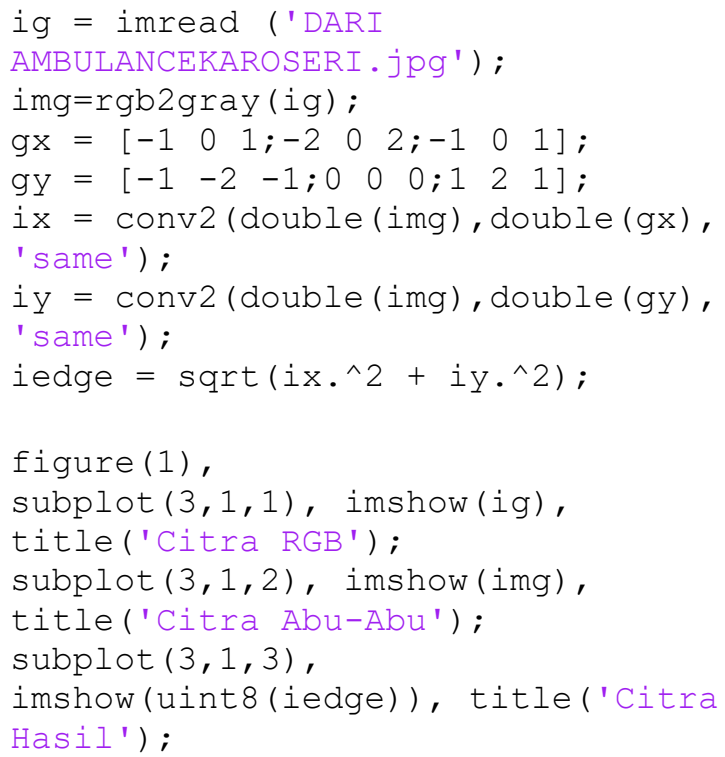

Setelah dilakukan uji melalui grayscale dan sobel terdapat hasil yang ditunjukkan pada gambar 7 yaitu :

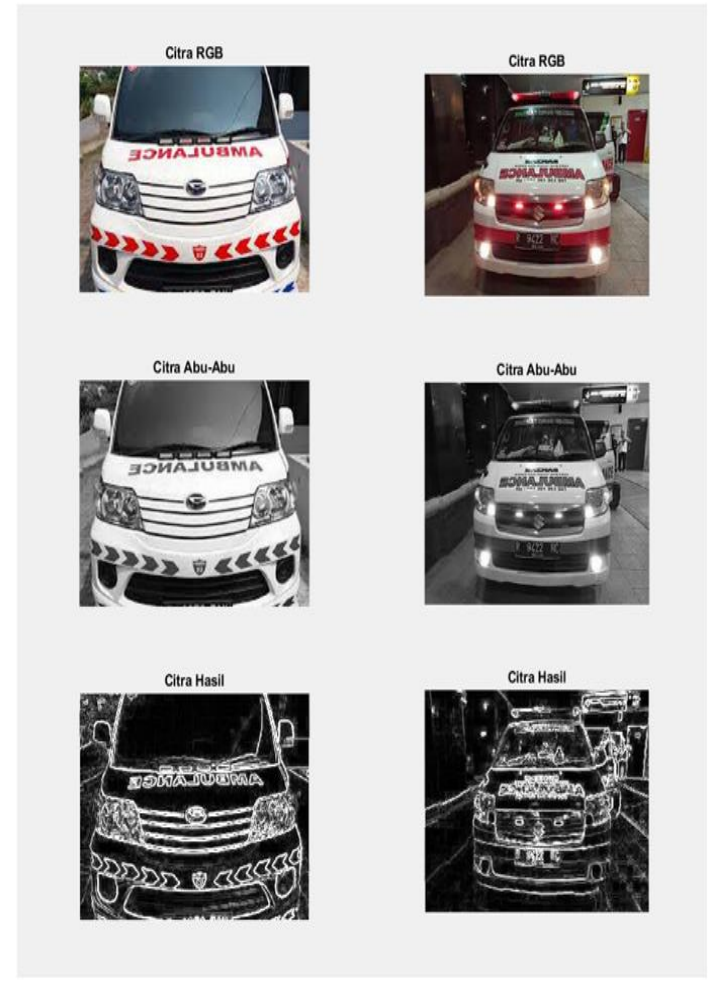

Gambar 7. Hasil uji Grayscale dan Sobel

Pada citra RGB menunjukkan gambar dengan text yang jelas di kedua buah objek, yang kemudian di proses ke citra grayscale terdapat perbedaan pada gambar baris ke dua dari kanan yang menunjukan bertabrakannya tulisan pada gambar dikarenakan terdapat beberapa tulisan yang berdekatan dengan text ambulance dan setelah dilakukan pendeteksian tepi dari citra hasil gambar pojok kanan bawah menunjukkan text tulisan yang tidak jelas dan tidak terbaca dari 4 pengujian objek yang di ambil secara berbeda menunjukkan hasil yang terdapat pada gambar no 5 dan gambar no 7 yang dijelaskan pada table No.1 yang di antaranya sebagai berikut :

Table 1. perolehan citra RGB, grayscale

\begin{tabular}{|c|c|c|c|}
\hline No & $\begin{array}{c}\text { Text } \\
\text { ambulance }\end{array}$ & Pixel & Sobel \\
\hline 1 & $\begin{array}{l}\text { Text } \\
\text { ambulance } \\
\text { Berwarna } \\
\text { merah }\end{array}$ & $450 \times 660$ & $\begin{array}{l}\text { Sangat } \\
\text { jelas }\end{array}$ \\
\hline 2 & $\begin{array}{l}\text { Text } \\
\text { ambulance } \\
\text { berwarna } \\
\text { biru }\end{array}$ & $450 \times 660$ & $\begin{array}{l}\text { Sangat } \\
\text { jelas }\end{array}$ \\
\hline 3 & $\begin{array}{l}\text { Text } \\
\text { ambulance } \\
\text { berwarna } \\
\text { biru muda }\end{array}$ & $450 \times 660$ & $\begin{array}{l}\text { Kurang } \\
\text { jelas }\end{array}$ \\
\hline 4 & $\begin{array}{l}\text { Text } \\
\text { ambulance } \\
\text { berwarna } \\
\text { merah } \\
\text { dengan } \\
\text { berberapa } \\
\text { tulis malam } \\
\text { hari }\end{array}$ & $450 \times 660$ & $\begin{array}{l}\text { Tidak } \\
\text { jelas }\end{array}$ \\
\hline
\end{tabular}

\section{SIMPULAN DAN SARAN}

\subsection{Kesimpulan}

Dari metode Sobel yang diujikan pada penelitian ini terdapat beberapa text ambulance yang terbaca secara jelas 
dengan warna tertentu yang terdapat pada ambulance dan di perlukannya tambahan perbandingan metode agar mendapatkan hasil dari perbandingan dengan sobel guna untuk membantu sebuah penelitian yang lebih baik. Dari data objek yang di ambil antara lain dari data internet ambulance karoseri dan data yang di ambil langsung dari kamera $\mathrm{Hp}$ vivo 7 menunjukkan perbedaan di setiap hasil yang tertera pada table 1 dari proses yang di uji menggunakan metode sobel.

\subsection{Saran}

Adapun pengembangan yang dapat dilakukan terhadap teknik untuk mendeteksi ambulance atau kendaraan darurat lain yang lebih kepada penangkapan objek berupa video yang terdapat pada CCTV dan terpasang di setiap lalu lintas guna untuk membantu kelancaran maupun keamanan dalam berkendara di setiap traffic light, serta dapat diketahui dari aspek efisiensi waktu dan prioritas dalam berkendara di keadaan darurat.

\section{UCAPAN TERIMA KASIH}

Terimakasih kepada Allah S.W.T yang telah memberikan kemudahan dan kelancaran dalam berfikir serta kesehatan selalu. Takluput pula dari kerjakeras saya sebagai penulis dan bimbingan dari Dr. Kusrini,M.Kom sebagai pembimbing satu dan Hanif Al Fatta, M.Kom sebagai pembimbing dua yang selalu memberikan arahan terhadap penelitian ini sehingga dapat terselesaikan.

\section{DAFTAR PUSTAKA}

Arief, $\mathrm{m}$ rizal, and $\mathrm{m}$ kom. 2017. “jurnal metode sobel edge detection analysis koi fish identification using sobel edge oleh : arif wicaksono dibimbing oleh : universitas nusantara pgri kediri surat pernyataan artikel skripsi tahun 2017." 01(06).
Canny, and Citra Ct. 1969. "Analisis Perbandingan Deteksi Tepi Operator Sobel Dan Operator." : 2-3.

Indraani, Sri Enggal, Ira Dhani Jumaddina, Sabrina Ridha, and Sari Sinaga. 2014. "Implementasi Edge Detection Pada Citra Grayscale Dengan Metode Operator Prewitt Dan Operator Sobel." : 1-5. https://www.academia.edu/10237558/ Implementasi_Edge_Detection_Pada_ Citra_Grayscale_dengan_Metode_Op erator_Prewitt_dan_Operator_Sobel.

Lusiana, Veronica. 2013. "Deteksi Tepi Pada Citra Digital Menggunakan Metode Kirsch Dan Robinson." Jurnal Teknologi Informasi DINAMIKA 18(2): 182-89.

Pribadi, Bagus, and Muchammad Naseer. 2014. "Sistem Klasifikasi Jenis Kendaraan Melalui Teknik Olah Citra Digital." Setrum 3(2): 35-39

Yulianti. 2017. "Pendeteksi Tempat Parkir Mobil Kosong Menggunakan Metode Canny." Coding Jurnal Komputer dan Aplikasi Untan 05 (03). 